\section{Gold on the Moon}

SIR,-Your Astronomy Correspondent states (Nature, 226,$580 ; 1970$ ) that the glazing within small lunar craters is an "awkward" discovery. Not so. It is generally our understanding of a new phenomenon which is awkward, or in the wrong direction.

Accepting the cogency of most of Professor T. Gold's explanation, but not the solar flare, I should like to suggest that the source of the radiation was the Earth's ionosphere during the last geomagnetic revorsal (700,000 years BP). The energy to heat tho ionosphere was derived from the ions accelerated by the new magnetic field increasing from zoro. The total energy requirement to glaze the Moon rocks on this hypothesis is less than $10^{-5}$ that required by the solar flare hypothesis. Two predictions can be made to support this hypothesis: (1) the age of the glazing on the rocks is 700,000 years; (2) the intensity of the glazing effect is diminished with distance from tho subEarth (sub-Tellurian ?) point on the Moon.

Yours faithfully,

C. W. Kaysing

2244 Sunset Crest Drive,

Los Angeles, California 90046.

\section{Solubility of Life}

Sir,-My attention was arrested by a sentencc (Nature, April 11, 1970) in the paper "Biological Molecules in their Excited States" by Eisinger, Lamola, Longworth and Gratzer, all presumably physicists: "The biologically interesting conditions are, of course, room temperature and aqueous solution. ..."

A marine biologist might object to "room temperature", But is it possible that physiologists have been treating cells as solutions for so long that physicists are taking it for granted that this is the state of living matter ?

$$
\text { Yours faithfully, }
$$

\section{H. R. CAtchPole}

Department of Pathology,

Uxiversity of Illinois.

This letter has been shown to the authors of the paper concerned, one of whom roplies as follows: Mea culpa, mea minima culpa! Wo physicists should never take sides in arguments between biologists. We were unaware that an issue existed, but we hope the physiologists will not scorn to pursue the hare that Professor Catchpole has started.

\title{
Announcements
}

\section{University News}

Four now professorial appointments have bcen made at Brunel University: Dr G. C. Bond, Johnson Matthey and Company, has been appointed to the chair of applied chemistry; Dr P. Feltham has been appointed to a new chair of applied physics; Dr P. Macdonald has been appointed to the chair of statistics and becomes head of the new Department of Statistics and Operational Research; Dr T. F. Slater, University College Hospital Medical School, has been appointed to the chair of biochemistry.

Professor John T. Dunlop, chairman of the University Committee on Governance and a member of the Committee of Fifteen, has been appointed dean of the Faculty of Arts and Sciences in Harvard University.

Two members of the faculty of the Massachusetts Institute of Technology have been appointed Institute professors. Professor Arthur T. Ippen is head of the Water Resources Division of the Department of Civil Engineering and director of the Water Resources and Hydrodynamics Laboratory; Professor Franco Modigliani is professor of finance in the Sloan School of Management and professor of economics.

The personal title of professor of tribology has been conferred on Dr William Hirst, senior lecturer in the Department of Applied Physical Sciences and head of the Unit on Lubrication and Wear in the University of Reading.

Dr J. K. A. Beverley, reader in medical microbiology, has been appointed to a personal chair in the Dopartment of Medical Microbiology, University of Sheffield.

The Cancer Research Centre of the University of Tehran School of Medicine has been extended to include a hospital unit, to deal with surgery, radiology, haematology and chemotherapy. Professor A. Habibi has been appointed director of the new centre, which has been named the Tadj Pahlavi Cancer Institute.

\section{Appointments}

Mr H. R. Galleymore, manager of the Newcastle Technical Centre, Proctor and Gamble Ltd, has been appointed a member of the University Grants Committee.

Dr P. G. Young, head of the Chemical Department of the British Standards Institution, has been appointed first secretary-general of the Comité Européen de Coordination des Normes.

The Board of Governors of the International Atomic Energy Agency has appointed Dr Kurt Waldheim, former Minister for Foreign Affairs of Austria, as chairman of the Safeguards Committce, and Mr J. A. K. Qartey (Ghana) and Academician Brunó F. Straub (Hungary) as vice-chairmen.

\section{Miscellaneous}

Awards from the Lady Tata Memorial Fund for research in leukaemia have been made to T. M. D. Dexter, Manchester; D. J. Reen, Dublin (full-time scholarships); T. J. E. Rytomaa, Helsinki; and B. Szafarz, Paris (expenses grants); the awards held by J. F. Dore, Paris, Y. Najean, Paris (expenses grants); O. Mach, Prague, and $\mathbf{P}$. Stryckmans, Brussels (part-time scholarships) have been renewed for the academic year 1970-71.

In view of the present lack of knowledge of the distribution of seaweed - an important factor in marine pollutionthe British Phycological Society will collaborate with the Biological Records Centre in mapping the seaweed distribution around the British Isles. The first stage will be the collation of record cards which will be sent in by collectors. Those wishing to participate in the scheme as collectors should apply to Dr T. A. Norton, Department of Botany, The University, Glasgow W2.

Corrigendum. In the article "Netherlands: Stop and Go on the Nuclear Merry-go-round" (Nature, 226, 1020; $1970)$, the figure given in the right-hand column of p. 1021, line 22, should be Dfl. $550,000,000$, not Df. 550,000 . 